\title{
Using creative drama in teaching English to young learners: Effectiveness on vocabulary development and creative thinking
}

\author{
Nergis Yumurtacl, Bahçeşehir University, Faculty of Educational Sciences, English Language Teaching \\ Department, nergisy544@hotmail.com, ORCID: https://orcid.org/0000-0001-8734-919X \\ Enisa Mede, Bahçeşehir University, Faculty of Educational Sciences, English Language Teaching \\ Department, enisa.mede@es.bau.edu.tr, ORCID: https://orcid.org/0000-0002-6555-5248
}

\begin{abstract}
The purpose of this study is to investigate and compare the effectiveness of creative drama and traditional instruction on the vocabulary development and creative thinking skills of young learners of English. The participants were 45 young learners (grade 2, age 7-8) and 2 teachers engaged in the primary English program in a private k-12 school in Istanbul, Turkey. In this quasi-experimental study, data were collected from the experimental group $(\mathrm{N}=23)$ engaged in creative drama-based lessons and control group $(\mathrm{N}=22)$ exposed to traditional instruction. Data were gathered quantitatively from preand post- vocabulary tests, pre- and post- creative thinking skills tests and, qualitatively from teachers' reflective journals. The findings revealed that creative drama-integrated instruction had a positive effect on the vocabulary development and creative thinking skills of young learners. Finally, the study provides pedagogical implications and recommendations on how to incorporate creative drama in elementary level English classrooms.
\end{abstract}

Keywords: Creative drama, Traditional instruction, Vocabulary development, Creative thinking skills, Teacher reflection

Received: 03.12 .2019

Accepted: 09.07.2020

Published:

\section{INTRODUCTION}

Dramatic experiences are named according to the educational purposes they have. Creative drama is one of those branches which aims at the development of the learners instead of performing a play (Freeman, Sullivan \& Fulton, 2003). That's why, it is described as processoriented rather than product-oriented. As the name implies, 'creative' drama necessitates learners to 'create' drama by using a literary text, a story, a dialogue or even a poem (Kelner, 1985). The aim of creative drama is not making learners memorize the texts word by word, on the contrary, they must use the 'content' of the literature. As it is not memorizing the sentences, students need to combine different skills. In this sense, Kelner (1985) deems drama as a synthesis of various educational concepts to a personally meaningful form.

When it comes to using creative drama in education, it is traced back when learnercentered approach is adopted. When learner-centered approach is put into the center of the instruction, creative drama is used as a teaching method, since it brings about self-expression, learning by doing and students' active involvement (Koyluoglu, 2010). John Dewey, Peter Slade, Brian Way, Harriet Finlay Johnson and Dorothy Heathcote are the pioneers who introduced creative drama to education actively. They all worked with children and shed light on the implementation of creative drama for young learners. Implementation of creative drama for young learners' creativity, involvement, self-expression, empathy, motivation and happiness is found effective in those studies (Dewey, 1921; Slade, 1954; Healthcote, 1984; Koyluoglu, 2010). Creative drama in education is linked with English language teaching in many previous studies (McCaslin, 1990; Demirel, 1990; Ipekboyayan, 1994; Fleming, 1995; Su Bergil, Ercevik \& Erdem; 2017). Creative drama is seen as an effective tool which improves learners' four skills, imagination, creative thinking skills and expression of emotions (Fleming, 1995; McCaslin, 1990; $\mathrm{Su}$ Bergil et. al., 2017). Also, the link between creative drama and vocabulary development is emphasized in many studies (Duffelmeyer \& Duffelmeyer, 1979; Stewing \& Buege, 1994). As Brown (1994) indicates, exposing students to the target language in early ages is an advantage to 
develop vocabulary. In other words, if the learner is younger, it is easier to build vocabulary knowledge. Therefore, creative drama is preferred as a teaching method for vocabulary development in young learners.

Creative drama is also related with creative thinking skills. In young learners, creative thinking skills can be defined as the processes which direct learners to evaluation, problemsolving and collaboration (McLoughlin, 1999). In other words, creative drama paves the way for learners to become the actors of their learning process. Contemplating 'as if's, role-playing, putting themselves in others' shoes, creating something new are some of the features of creative drama which are linked to creative thinking. Gardner (1993), the founder of Multiple Intelligences Theory, divides intelligence types into eight groups such as linguistic, bodily-kinaesthetic, spatial, musical, logical-mathematical, interpersonal, intrapersonal and naturalist intelligence. He deems creative drama as an effective teaching method to reach students with different intelligences, since the intelligences are inherent in the nature of the creative drama (Moore, 2004).

Over the last decades, research emphasized the effects of creative drama in young learners' classrooms (Campbell, 2008; Baraldi, 2009; Anna et al., 2011; Albalawi, 2014; Barreto, 2014). The obtained findings highlighted the importance of incorporating creative drama activities in young learners' classrooms to develop their vocabulary and improve their creative thinking skills.

To begin with, Campbell (2008) investigated the impact of drama on 4th and 5th graders' academic achievement. There were 1,149 students, half of them were in the experimental and half of them were in the control group. The study was comprised of qualitative and quantitative data collection tools, which were the standardized test of New Jersey Assessment of Skills and Knowledge (NJASK5), students' grades and lastly, students' and teachers' reflections. The results revealed that the students taught by drama outperformed in the achievement tests when compared to the students who were taught with traditional methods.

Baraldi (2009) studied the effect of using drama techniques in elementary classes to teach a second language for content knowledge. The participants were 27 students who were in a mixed class of 4th-5th grades. The data were gathered through qualitative data collection tools such as field notes, observations and interviews. The results suggested that participants were happy about using drama in the classroom, they learned the academic content deeply, and therefore drama techniques can be used for other academic areas.

In the study of Anna et al. (2011), she aimed to assess the effect of drama on kindergarten students' academic achievement. There were 83 students in experimental group while the control group is made up of 20 students. Teachers and students filled a pre-test questionnaire, drama is implemented, students did a story-telling test, and finally teachers and students filled the same questionnaire as the post-test. The findings revealed that teachers' perceptions about drama implementation changed in a positive way, students became more confident and cooperative and their verbal expression in the storytelling improved.

Albalawi's (2014) study aimed to see the effect of drama on students' creative thinking. Participants 47 intermediate level female students, 23 of which were assigned to the experimental and 24 of which were assigned to the control group. Torrance Creativity Test was used for the pre- and the post-test. When the means of the pre- and the post tests of the both groups compared, the results revealed that there was a statistically significant difference between the experimental and the control group in terms of creative thinking.

Barreto (2014) aimed to see the impact of educational drama on language acquisition. In the implementation of the drama, a context was given to the students in which they needed to use their problem-solving skills. The results revealed that students' listening and speaking skills were developed thanks to the interactions between students and students besides students and teachers.

Considering foreign language education in Turkey, drama has started to gain attention since 1997. Many researchers explored the use of drama activities while TEYLs and shared prominent findings related to their effect on vocabulary development and creative thinking skills (Sarac, 2007; Demircioglu, 2010; Köylüoğlu, 2010; Bulut- Yılmaz, 2010; Çelen \& Akar-Vural, 2011; Taskın, 2013; Dollar \& Yilmaz, 2017). 
Saraç (2007) studied the effect of creative drama on young learners' speaking skills. Participants were 25 young learners whose age ranged between 7-9 years old. They were expected to write about their feelings and thoughts when creative drama techniques were used. The recorded lessons and students' diaries were interpreted by the researcher and the results revealed that students' speaking ability increased as well as their self-confidence after creative drama implementation.

In Demircioğlu's study (2010) the aim was to see the possible effect of creative drama on young learners' vocabulary development. Participants were 3rd graders who were assigned randomly either to the experimental or to the control group. There were 14 boys and 11 girls in the control group, and 13 boys and 12 girls in the experimental group. Each lesson was comprised of a story to warm-up, a game for the main activity and an improvisation activity for the postactivity. The control group, on the other hand, was taught new words with the course book by using traditional methods. The results revealed that drama implementation was a more effective method to teach vocabulary than traditional vocabulary teaching methods in young learners' classrooms.

Çelen and Akar-Vural (2011) aimed to investigate the effects of using creative drama techniques on 4th grade students' English learning. Participants were 97 students who were divided into an experimental group and a control group. Data was collected through the English Language Achievement Test and the Personal Information Form. The results revealed that creative drama techniques had a positive effect on young learners' academic success in English. Köylüoğlu (2010) used creative drama to teach simple present tense and develop students' speaking skills in a high school. The participants were grouped as experimental and control group, either of which 17 students had. For grammar, the same pre- and post- test used and for speaking, again pre and post-test design is preferred but the speaking test was different from the grammar test. While drama techniques were used in the experimental group, the control group were taught with traditional methods. The results revealed that the students of the experimental group scored better than the control group, and creative drama activities fostered students' speaking.

Bulut-Yılmaz (2010) conducted a research study on creative drama's effect on students' vocabulary development. There was an experimental and control group design in which students in the experimental group were taught vocabulary with creative drama techniques. Also, Gardner's (1985) Attitude Measurement Survey was used to see students' thoughts and feelings about drama lessons. It was concluded that the students in experimental group performed better in terms of vocabulary knowledge and students' perceptions about drama lessons were positive.

Taskin (2013) aimed to explore the relationship between creative drama and students' achievement in science. Participants were 60 students in the 5th grade which were randomly assigned either to the experimental or to the control group. Experimental group was taught the subject with creative drama methods and a science achievement test besides a scientific process skills test were used for the pre- and the post-test. The results revealed significant differences in the means of creative drama applications, science achievement and scientific process skills between the groups and between the pre- and the post-tests.

Dollar and Yllmaz (2017) studied 9th grade students' and their EFL teachers' attitudes towards the use of drama in English classes. Participants were 11 EFL teachers in the Department of Foreign Language Teaching and 23 Turkish students learning English. It was a qualitative research which aimed at finding students and teachers' reflections on drama. Besides reflections, the study also examined if drama had a positive effect on students' oral skills. Data collection tools were semi-structured interviews with EFL teachers, teacher logs and student feedback note cards. The results revealed that students gained the ability to explore new learning techniques with drama and they developed a positive attitude towards English.

The present study aims to incorporate creative drama in an English classroom and investigate its effectiveness on the vocabulary development and creative thinking skills of young learners. Specifically, this study attempts to investigate and compare the effects of creative drama and traditional instruction on the vocabulary development and creative thinking skills of $2^{\text {nd }}$ grade Turkish learners of English studying in a private k-12 school in Istanbul, Turkey. Finally, 
this study attempts to find out the reflections of $2^{\text {nd }}$ grade English teachers about using creative drama in their classroom practices.

\section{Research Questions}

To meet the objective of this study, the following research questions were addressed:

1. To what extent does creative drama-integrated instruction have impact on the vocabulary development of $2^{\text {nd }}$ grade learners of English?

2. To what extent does traditional instruction have impact on the vocabulary development of $2^{\text {nd }}$ graders?

3. Is there any significant difference between using creative drama-integrated and traditional instruction on the vocabulary development of the participants?

4. What changes does creative drama-integrated vs. traditional instruction have on the creative thinking skills of the participants?

5. What are the reflections of the teachers about using creative drama in $2^{\text {nd }}$ grade English class?

\section{METHODS}

For the purposes of this study, mixed-method approach was adopted as a research design since the data were obtained via quantitative and qualitative data collection methods. Specifically, quantitative data were gathered from pre- and post- vocabulary tests and pre- and post- creative thinking skills tests to examine the effects of creative drama vs traditional instruction on the vocabulary development and creative thinking skills of young learners whereas the qualitative data were collected from teacher reflective journals about creative drama-integrated English lessons. This study was conducted at a private primary k-12 school in İstanbul, Turkey. There were 4 classes and 92 2nd graders in total. The experimental group was the class that the researcher had been teaching for 2 years, but the class for the control group was chosen randomly. There were 45 beginner-level students whose age ranged between 8-9 years in those two classes. In the experimental group, there were 11 girls and 12 boys while in the control group there were 11 boys and 11 girls. As for the participating teachers in this study, there were 2 participant teachers, each teaching English to 2 nd graders. They were working at the same institution at least 1 year. They were both 26-year-old female English teachers of Turkish nationality. They had their BA in the Department of English Language Teaching (ELT). Besides this, the experimental group's teacher had her MA in the same department. Finally, the teacher of the experimental group had 2 years of experience while the teacher of the control group had 3 years of experience.

\section{Data Collection Tools}

In this study, vocabulary development pre- and post- test was prepared by combining 4 different units of the 2nd graders' main course book (Appendix A). The test was comprised of 4 different parts; Part A, Part B, Part C, Part D which were divided according to the units. There were 4 units to be taught and each of them had different themes.

Table 1. Analysis of the questions in vocabulary pre- and the post-test

\begin{tabular}{lccc}
\hline \multicolumn{1}{c}{ Parts } & Themes & Number of questions & Question type \\
\hline A & Sharing and Helping & 10 & Matching \\
B & Needs and Wants & 10 & $\begin{array}{c}\text { Paragraph } \\
\text { Completion }\end{array}$ \\
C & Jobs and Money & 10 & Sentence Completion \\
D & Places We Live & 10 & Multiple Choice \\
\hline
\end{tabular}


To test creative drama's effect on young learners' creativity, Torrance Tests of Creative Thinking - Figural (TCTT-Figural) was used. TCTT was developed by Torrance in two types which were verbal and figural. Both TCTT-Verbal and TCTT-Figural had two parallel forms, Form A and Form B. The TTCT-Figural had 3 questions each of which was stimulated by a picture. The questions were comprised of picture construction, picture completion, and repeated figures of lines or circles (Appendix B). Participants needed 10 minutes for each question, i.e. the test took 30 minutes.

Teachers' Reflective Journals were kept by the two participant teachers for a total of 2 months (16 lessons, each lesson $40 \mathrm{~min}$.) (Appendix C). The journals were kept after each lesson (16 lessons in total). Specifically, the teachers' shared their observations, experiences, reflections and the difficulties they experienced in their classroom practices.

\section{Implementation of Creative Drama}

As explained in the previous section of this study, there are four data collection tools; pre- and post- vocabulary test, pre- and post- creativity skills test, reflective teacher journals and student interviews. Target vocabulary items were chosen from 2 nd graders' course book, i.e. the content was decided by taking into consideration the following 4 units of the book. While the control group was taught with the course book, the experimental group was taught the target content with creative drama techniques. Implementation of drama techniques to teach target items lasted 8 weeks. Each week, 2 lessons at the same day at the same hour were allocated for teaching the content with using creative drama as a teaching method. The creative drama techniques used were warm-up, pantomime (mime), role-play, and drama games. As the creativity test was based on drawing, also drawing lessons were put in the program. In total, in each 2 weeks, there were 4 warm-up lessons and 2 lessons of mime, role-play, drama games and drawing. The number of lessons were kept equal on purpose; however, the number of warm-up activities were more than the others as each lesson started with a warm-up to familiarize young learners with the topic. The following section provides brief information about the four drama techniques followed by how these techniques were incorporated in the 2 nd grade English class.

Table 2. Number of drama techniques used by weeks

\begin{tabular}{llllll}
\hline & Warm-up & Mime & Role-play & $\begin{array}{l}\text { Drama } \\
\text { Games }\end{array}$ & Drawing \\
\hline Week $1+2$ & 4 & 2 & 2 & 2 & 2 \\
Week $3+4$ & 4 & 2 & 2 & 2 & 2 \\
Week $5+6$ & 4 & 2 & 2 & 2 & 2 \\
Week $7+8$ & 4 & 2 & 2 & 2 & 2 \\
\hline
\end{tabular}

\section{Data Analysis Procedures}

In this study, for the quantitative data collection tools, the same vocabulary development pre- and post- test and creativity pre- and post- test were used. The data gathered from the pre- and posttests implemented in both classes were statistically analyzed. Statistical Package for the Social Sciences (SPSS) version 22.0 were used to interpret the data. The pre- and the post- vocabulary test results of the experimental and control groups were compared by using dependent sample ttest. Then, the results of the two groups were compared by through the independent samples ttest to see if the incorporation of creative drama had an impact on the vocabulary development of the participants. Regarding the creative thinking skills of the 2nd graders, the data gathered from pre- and post- test was counted and interpreted in accordance with the scale of TCTT-F, which analyzed the data according to the subscales such as frequency, originality, elaboration, 
abstractness of titles and resistance to premature closure. As stated by Kim (2006), frequency is counted as the number of figures drawn by the student, originality as the ability to produce uncommon or unique responses. Scoring procedure counts the most common responses as 0 and others as 1 . Then, the student's total score is determined. Elaboration is determined according to the colors and figures used. Abstractness of titles means students' using detailed abstract labeling instead of one- word concrete labelling and resistance to premature closure is the ability to feel open, produce as wide as and as much as possible. (p.5).

Finally, for the qualitative data, reflective teacher journals analyzed thematically by two experts in English Language Teaching (ELT). The perceptions, feelings and comments related to teaching and learning English using creative drama were identified according to the repeated features in the journals. Those repeated features were grouped as dominant themes. After those themes were determined, they were interpreted parallel to the research questions of the present study.

\section{RESULTS}

This chapter presents the findings of the current study which aims at finding the possible effect of creative drama implementation on young learners' vocabulary development and creative thinking skills besides the participant teachers' and students' perceptions. In this section, the findings of the pre- and post- vocabulary test, post vocabulary tests of the two groups, post creative skills tests of the two groups, and the reflective teacher journals.

\section{Findings about the Effect of Creative Drama-integrated Instruction on the Vocabulary Development of $2^{\text {nd }}$ Grade English Learners}

Table 3. Comparison of the pre- and post-vocabulary test results of the experimental group

\begin{tabular}{|c|c|c|c|c|}
\hline Class & Test & $\mathbf{M}$ & SD & $\mathbf{p}$ \\
\hline \multirow{14}{*}{$\begin{array}{c}\text { Experimental } \\
\text { Group } \\
(\mathrm{N}=23)\end{array}$} & Post total & 33.48 & 6.85 & \multirow{3}{*}{$.01 *$} \\
\hline & & & & \\
\hline & Pre total & 19.87 & 8.86 & \\
\hline & Post Part A & 9.52 & 1.04 & \multirow{3}{*}{.21} \\
\hline & & & & \\
\hline & Pre Part A & 7.30 & 2.65 & \\
\hline & Post Part B & 8.26 & 2.58 & \multirow[b]{2}{*}{.33} \\
\hline & Pre Part B & 3.74 & 2.54 & \\
\hline & Post Part C & 7.65 & 2.39 & \multirow{3}{*}{.07} \\
\hline & & & & \\
\hline & Pre Part C & 3.65 & 3.54 & \\
\hline & Post Part D & 8.04 & 2.01 & \multirow{3}{*}{$.01^{*}$} \\
\hline & & & & \\
\hline & Pre Part D & 5.17 & 2.23 & \\
\hline
\end{tabular}

* p<.05; Part A: Sharing and Helping; Part B: Needs and Wants; Part C: Jobs and Money; Part D: Places We Live

As for Part A, the post-test result of the experimental group was not statistically higher than their pre-test result $(\mathrm{p}=.21, \mathrm{p}>.05)$. Also, in Part $\mathrm{B}(\mathrm{p}=.33, \mathrm{p}>.05)$ and Part $\mathrm{C}(\mathrm{p}=.07, \mathrm{p}>.05)$, 
their post test results were not statistically higher than their pre-test results. However, in Part D, there was a statistically significant difference between the experimental group's pre- and posttest result $(\mathrm{p}=.01, \mathrm{p}<.05)$. As it can be seen from Table 3 , the post-vocabulary test result of the experimental group was significantly higher than the pre-vocabulary test result in total $(p=.01$, $\mathrm{p}<.05)$. Hence, it can be concluded that creative drama lessons in the present study resulted in a significant improvement in the development of the participants' vocabulary knowledge.

\section{Findings about the Effect of Traditional Instruction on the Vocabulary Development of $2^{\text {nd }}$ Grade English Learners}

Table 4. Comparison of the pre- and post-vocabulary test results of the control group

\begin{tabular}{|c|c|c|c|c|}
\hline Class & Test & $\mathbf{M}$ & SD & $\mathbf{p}$ \\
\hline & Post total & 27.55 & 8.78 & \multirow{3}{*}{$.01^{*}$} \\
\hline & & & & \\
\hline & Pre total & 19.18 & 9.07 & \\
\hline & Post Part A & 9.41 & 1.26 & \multirow{3}{*}{$.01^{*}$} \\
\hline & & & & \\
\hline Control Group & Pre Part A & 7.68 & 3.06 & \\
\hline \multirow[t]{9}{*}{$(\mathrm{N}=22)$} & Post Part B & 5.77 & 3.02 & \multirow{3}{*}{$.04^{*}$} \\
\hline & & & & \\
\hline & Pre Part B & 3.45 & 2.22 & \\
\hline & Post Part C & 5.32 & 4.09 & \multirow{3}{*}{$.01^{*}$} \\
\hline & & & & \\
\hline & Pre Part C & 3.09 & 3.80 & \\
\hline & Post Part D & 7.05 & 2.28 & \multirow{3}{*}{$.01^{*}$} \\
\hline & & & & \\
\hline & Pre Part D & 4.95 & 2.36 & \\
\hline
\end{tabular}

$* \mathrm{p}<.05$

Regarding the Part A, the post-test result of control group was statistically higher than their pre-test result $(\mathrm{p}=.01, \mathrm{p}<.05)$. Also, in Part $\mathrm{B}$, there was a statistically significant difference between their scores in the pre- and the post-test $(\mathrm{p}=.04, \mathrm{p}<.05)$. Accordingly, in Parts $\mathrm{C}(\mathrm{p}=.01$, $\mathrm{p}<.05)$ and $\mathrm{D}(\mathrm{p}=.01, \mathrm{p}<.05)$, the control group's post test result was statistically higher than their pre-test result.

In addition, as it can be seen from Table 4, the post-vocabulary test result of control group was significantly higher than the pre-vocabulary test result in total $(\mathrm{p}=.01, \mathrm{p}<.05)$. Therefore, it can be concluded that traditional instruction also resulted in a significant improvement in the development of the participants' vocabulary knowledge. 
Findings about the Effect of Creative Drama-Integrated Instruction and Traditional Instruction on $2^{\text {nd }}$ Grade English Learners' Vocabulary Development

Table 5. Comparison of the pre-test results of the experimental and control groups

\begin{tabular}{|c|c|c|c|c|c|}
\hline Test Score & Class & $\mathbf{N}$ & $\mathbf{M}$ & SD & $\mathbf{p}$ \\
\hline \multirow{4}{*}{ Pre total } & Experimental & 23 & 19.87 & 8.86 & \multirow{4}{*}{0.80} \\
\hline & Group & & & & \\
\hline & & & & & \\
\hline & $\begin{array}{l}\text { Control } \\
\text { Group }\end{array}$ & 22 & 19.18 & 9.07 & \\
\hline \multirow{4}{*}{ Pre Part A } & Experimental & 23 & 7.30 & 2.65 & \multirow{4}{*}{0.66} \\
\hline & Group & & & & \\
\hline & & & & & \\
\hline & $\begin{array}{l}\text { Control } \\
\text { Group }\end{array}$ & 22 & 7.68 & 3.06 & \\
\hline \multirow{4}{*}{ Pre Part B } & Experimental & 23 & 3.74 & 2.54 & \multirow{4}{*}{0.69} \\
\hline & Group & & & & \\
\hline & & & & & \\
\hline & $\begin{array}{l}\text { Control } \\
\text { Group }\end{array}$ & 22 & 3.45 & 2.22 & \\
\hline \multirow{4}{*}{ Pre Part C } & Experimental & 23 & 3.65 & 3.54 & \multirow{4}{*}{0.61} \\
\hline & Group & & & & \\
\hline & & & & & \\
\hline & $\begin{array}{l}\text { Control } \\
\text { Group }\end{array}$ & 22 & 3.09 & 3.80 & \\
\hline \multirow{4}{*}{ Pre Part D } & Experimental & 23 & 5.17 & 2.23 & \multirow{4}{*}{0.75} \\
\hline & Group & & & & \\
\hline & & & & & \\
\hline & $\begin{array}{c}\text { Control } \\
\text { Group }\end{array}$ & 22 & 4.95 & 2.36 & \\
\hline
\end{tabular}

$* \mathrm{p}<.05$

As it can be seen in Table 5, there was no statistically significant difference between the pre-test results of the experimental and the control group in total ( $p=.80, p>.05)$. Hence, it can be concluded that participants in both classes were similar in terms of the vocabulary set at the beginning, i.e. they started the process with similar vocabulary knowledge. The same result was valid in each part of the test, as in Part A ( $p=.66, p>.05)$, in Part B ( $p=.69, p>.05)$, in Part C ( $p=0.61$, $p>.05)$ and in Part D ( $p=.75, p>.05)$ neither of the groups scored significantly higher than the other group. 
To be able to conclude that participants who were exposed to creative drama- integrated lessons scored significantly higher than the ones who were taught with traditional instruction, Table 6 shows the mean, standard deviation and $\mathrm{p}$ value of the post- test results of the both groups.

Table 6. Comparison of the post-test results of the experimental and control groups

\begin{tabular}{|c|c|c|c|c|c|}
\hline Test & Class & $\mathbf{N}$ & M & SD & p \\
\hline \multirow{4}{*}{ Post total } & Experimental & 23 & 33.48 & 6.85 & \multirow{4}{*}{$.02^{*}$} \\
\hline & Group & & & & \\
\hline & & & & & \\
\hline & $\begin{array}{c}\text { Control } \\
\text { Group }\end{array}$ & 22 & 27.55 & 8.78 & \\
\hline \multirow{4}{*}{ Post Part A } & Experimental & 23 & 9.52 & 1.04 & \multirow{4}{*}{.74} \\
\hline & Group & & & & \\
\hline & & & & & \\
\hline & $\begin{array}{l}\text { Control } \\
\text { Group }\end{array}$ & 22 & 9.41 & 1.26 & \\
\hline \multirow{4}{*}{ Post Part B } & Experimental & 23 & 8.26 & 2.58 & \multirow{4}{*}{$.01^{*}$} \\
\hline & Group & & & & \\
\hline & & & & & \\
\hline & $\begin{array}{l}\text { Control } \\
\text { Group }\end{array}$ & 22 & 5.77 & 3.02 & \\
\hline \multirow{4}{*}{ Post Part C } & Experimental & 23 & 7.65 & 2.39 & \multirow{4}{*}{$.02^{*}$} \\
\hline & Group & & & & \\
\hline & & & & & \\
\hline & $\begin{array}{c}\text { Control } \\
\text { Group }\end{array}$ & 22 & 5.32 & 4.09 & \\
\hline \multirow{4}{*}{ Post Part D } & Experimental & 23 & 8.04 & 2.01 & \multirow{4}{*}{.13} \\
\hline & Group & & & & \\
\hline & & & & & \\
\hline & $\begin{array}{c}\text { Control } \\
\text { Group }\end{array}$ & 22 & 7.05 & 2.28 & \\
\hline
\end{tabular}

$* \mathrm{p}<.05$

With regard to the Part $A(p=.74, p>.05)$ and Part $D(p=.13, p>.05)$, participants' post test results were similar, i.e. there was no statistically significant difference between the two groups. However, in the Part B ( $\mathrm{p}=.01, \mathrm{p}<.05)$ and Part $\mathrm{C}(\mathrm{p}=.02$, $\mathrm{p}<.05)$, the experimental group's posttest results were statistically higher than the post-test results of the control group. Furthermore, there was statistically significant difference between the two groups' post-test results in total 
$(\mathrm{p}=.02, \mathrm{p}<.05)$. In other words, the experimental group who had creative drama-integrated instruction scored significantly higher in the post-vocabulary test than the control group who instructed with the traditional method. Therefore, it can be concluded that creative dramaintegrated lessons had a positive effect on $2^{\text {nd }}$ graders' vocabulary development.

\section{Findings about the Effect of Creative Drama-Integrated Instruction on $2^{\text {nd }}$ Grade English Learners' Creative Thinking Skills}

The performance of the 2nd graders was evaluated by using 5 subscales which were fluency, originality, elaboration, abstractness and resistance to premature closure. The participants' drawings were divided into three parts; use, combine, complete, and interpreted separately. First, the experimental groups' drawings in the pre- and the post- creative thinking skills test results, then control group's pre-and post-test results were analyzed.

\section{The difference between the pre- and post- test results of the experimental group}

According to the drawing performance of the experimental group, the number of drawings increased from 12 items to 18 items drawn in the post-test. As for the originality, the participants' score was 9 in the pre-test as seven young learners drew 'drink' and five young learners drew 'person'; however, in the post-test the participants' score was 17 since three of them drew 'person' and another three students drew 'drink' which showed an increase in the originality.

Considering elaboration, the drawings and the titles got detailed as all participants used colors in their drawings of the post-test while only 14 of them used colors in the pre-test. Similar to previous parts, the participants used titles such as 'egg boiling in hot water', 'color changing flower' or 'video game' instead of the titles like 'game' or 'traffic'. Finally, the labelling procedure changed from one-word long titles to two or three-word long titles.

\section{The difference between the pre- and post- test results of the control group}

According to the drawing performance of the control group in the pre-test, the number of the drawings in terms of fluency slightly increased as 15 items were drawn in the pre-test, while in the post test, 16 items drawn. With regard to originality, the participants' score was 10 in the pretest as 4 learners drew 'home' and 2 young learners drew 'submarine' and 'golf'. On the contrary, in the post-test, the participants' score was found to be 12 . This finding also reveals an increase in the variety as the participants preferred to draw 'flower', 'game', 'submarine' and 'box'. Considering elaboration, none of the participants used colors in their drawings of the post-test while 3 of them used colors in the pre-test. Finally, they did not use complicated, three or twoword long titles either. Instead they used one-word concrete titles instead such as, 'home', 'flower' and 'box'.

In short, when the scores were compared, it was seen that the experimental group's scores of the post-test were higher than the score they got in the pre-test. The participants of the experimental group drew more frequent, original and elaborated pictures with more abstract titles. However, the participants of the control group could not provide more frequent, original and elaborated drawings than they did in the pre-test. Therefore, it could be concluded that creative drama-integrated instruction was more effective than traditional instruction to develop creative thinking skills of the 2 nd graders.

\section{Findings about the Teacher's Reflective Journals about using Creative Drama in a $2^{\text {nd }}$ grade English Classroom}

The teacher of the experimental group (T1) and the teacher of the control group (T2) kept journals in all along the process from the vocabulary development pre-test to the creative thinking skills post-test. In other words, they both wrote their reflections on the lessons that the participants took the pre- and post-tests of vocabulary and creative thinking skills besides the 16 lessons they taught. Their journals were similar in terms of the test-taking processes; however, the journal entries of the experimental group's teacher were different from the ones of the control group in terms of the learners' interest in the activities, the ideas they came up with, the ambition they had in games, the improvement in using their bodies and speaking. 
In the following part, first the similarities are summarized, and then the reflections of the experimental group's teacher are grouped regarding the dominant themes of her journal.

The similarity between the journals was that both groups' participants asked the reason why they were taking those tests and whether the teacher was going to score it or not. Not only in the prevocabulary test, but also in the post-test the participants were anxious if they were going to get scores or not.

Another similarity that both teachers observed was the participants' reactions to parts of the tests. The teachers observed that $2^{\text {nd }}$ graders were good at Part A related to matching pictures with the words, but they had difficulty in the Parts B and C which were about sentence and paragraph completion. Although the participants from the both classes had some properties in common as explained above, the vocabulary development process was different in those classes as the experimental group's teacher wrote about her students' increasing interest in the activities, the creative ideas they came up with, the ambition they had in games, the improvement in using their bodies and the improvement in speaking.

According to experimental group's teacher, the students' interest in English lessons were increased, they started to use their creativity more, they got ambitious, and lastly, their speaking and use of their bodies improved with the implementation of creative drama lessons.

Increasing interest in activities. When the reflective journals were analyzed, the experimental group's teacher indicated in her journal that the learners felt interested and they were quite enthusiastic for the creative drama activities.

[...] They wanted to participate in every action. In the break time they asked me if we would continue in the following lesson. They were like "We continue next lesson teacher? Pleaseeeeee!!!" (T1, Journal Data, 15.02.2019)

The creative ideas they came up with. The findings obtained from the journal of the experimental group revealed that the teacher often wrote about the students' ideas.

[...] They had to tell a sentence by using the word in their card. "Pot is red." was okay, but instead, one of my students told "I make pop-corn in the pot." I was surprised! (T1, Journal Data, 08.02.2019)

Their ambition in games. Based on the reflections of the teacher of the experimental group, using games with young learners could pose some problems regarding their desire of winning.

[...] While the groups were performing their 'random sound stories', the other groups told that they were better and made fun of the performing group. I warned them since they made their friends feel ashamed. I think this kind of reactions inhibit students from showing their full potentials. (T1, Journal Data, 15.02.2019)

The improvement in using their bodies. The findings based on the reflections of the teacher revealed that the participants of the experimental group improved in using their body language.

[...] They were rehearsing for role-playing the story "The City Mouse and the Country Mouse'. Even when they were practicing, some groups included their body language; they run in the classroom, they were surprised, they became happy, ate apples etc. In the performance part, they were quite good at using their bodies while they were running away from the cat, going to the orchard and picking apples, eating pop-corn and watching a movie at the movie theater at the same time. (T1, Journal Data, 29.03.2019)

The teacher's observations were also in tune with the studies conducted previously in that area. The teacher of the experimental group was satisfied with the creative drama lessons since she observed that creative drama-integrated instruction gave the students the opportunity to engage in English lessons, use their creative thinking skills, speak and move more. Hence, it can be concluded from the teacher's reflections that creative drama lessons had a positive impact on $2^{\text {nd }}$ graders physically and intellectually.

\section{DISCUSSION AND CONCLUSIONS}

The improvement in $2^{\text {nd }}$ grade English learners' vocabulary knowledge after they were exposed to creative drama-integrated instruction was attributable to the method itself which was a learner-centered approach. In learner-centered approaches, learners constructed knowledge 
themselves by actively participating in the learning process (Koyluoglu, 2010). In this sense, creative drama as a teaching method of learner-centered approaches not only improved students' involvement, but they also provided students with the environment where they built their own knowledge (Dewey, 1921; Slade, 1954; Heathcote, 1984; Koyluoglu, 2010). Active involvement to the learning process made it easier for students to develop vocabulary knowledge and this finding conformed to the findings of the studies which linked vocabulary development with creative drama activities (Duffelmeyer \& Duffelmeyer, 1979; Stewing \& Buege, 1994).

Not only creative drama-integrated lessons, but also the traditional instruction was successful in terms of developing the participants' vocabulary knowledge. In total of the post-test, there was an increase in the performance of the control group, which could be attributable to the fact that the relevant units had not been introduced then. In other words, before the pre-test, the participants had not known the themes and subjects taught, which could be the reason for the control group's scoring significantly higher in the post-vocabulary test. To sum up, traditional instruction was also effective in helping 2 nd graders to improve their vocabulary; however, the difference between the post-tests of the experimental and control group showed that the learners could have scored better if they had been taught with using creative drama-integrated instruction.

The statistically significant difference between the groups could be attributed to the context that the vocabulary items were introduced. The children in the experimental group were expected to use their four skills in the warm-up, pantomime, game and roleplay activities, which provided the learners with the meaningful context that they can use their all language resources. Demircioğlu (2010) considered students' using their language resources vital for meaningful production, which enhanced their linguistic abilities. Therefore, it can be concluded that the experimental groups' success might be stemmed from the creative drama's creating the meaningful context in which children cherished. In addition, the participants were sitting for long hours in regular lessons. However, as they were young learners, they needed to be kept active and busy. In this respect, creative drama activities were demanding physically and intellectually at the same time, which created a convenient context for young learners (Uysal \& Yavuz, 2015). The participants might find the regular lessons boring as the traditional instruction was made up of 'matching' and 'fill in the blanks' activities done with the book. The participants of the control group followed the activities in the book, which kept the participants of the control group quite passive when compared to the experimental group's participants.

The difference between the Torrance test scores was attributable to the creative drama activities' addressing students with intelligences that were not reached through traditional instruction (Clark, 2013). Creative drama activities demanded students to explore, imagine and create in contrast to traditional instruction. According to Clark, creative drama-integrated instruction improved learners' interpretation and creativity by providing them looking at the same thing with new perspectives, which was a finding of the present study, too. The students decided about the things they drew, they made decisions in the role-play activities, they needed to work cooperatively with their group members, which were intellectually demanding activities. In this respect, Ozdemir and Cakmak (2008) indicated that group works, sharing responsibilities, socialization and empathy were the skills developed with creative drama activities, that's why creative drama implementation improved children's using creative thinking skills.

The teacher of the experimental group emphasized that the young learners' use their creativity when they were given the opportunity. Following the 'matching' and 'fill in the blanks' activities of the coursebook did not provide the learners with some space to express their ideas. However, the various activities such as miming, role-play, drawing and games made them get in the process and use their imagination. Wooster (2004) argued for including creative drama activities to facilitate learners' use of reflection and imagination, which nourished children's creativity. Moreover, Desialova (2009) argued for creative drama activities since they were able to develop children's mental power by making them think and imagine constantly.

In brief, the findings of this study revealed that both the creative drama-integrated instruction and the traditional instruction had a positive effect on the vocabulary development of the 2nd grade learners of English. However, when the post-vocabulary test results of the 
experimental and the control group were compared, a statistically significant difference was found between the two groups. Specifically, the experimental group scored higher than the control group. Also, creative drama lessons had a positive effect on 2nd graders' creative thinking skills when compared to traditional instruction. Moreover, the reflections of the teachers supported this finding. In other words, the teacher's reflections showed the increase in students' interest, use of imagination, creativity, ambition, and speaking and body movements after integrating creative drama in English lessons.

\section{REFERENCES}

Albalawi, B. (2014). Effectiveness of teaching English subject using drama on the development of students' creative thinking. IOSR Journal of Research \& Method in Education, 4(6), 54-63.

Anna N. N. H., Ping-kuen C., Simon T. K. W., \& Mavis W. J. H. (2011). How effective is a drama-enhanced curriculum doing to increase the creativity of preschool children and their teachers? The Journal of Drama and Theatre Education in Asia,

(2)1, 21-48.

Baraldi, S. M. (2009). Drama and theater practices in the elementary classroom that create conductive environments for non-English speakers' English language acquisition (Doctoral dissertation). Arizona State University. UMI Number: 3380660.

Barreto, E. A. (2014). Educational drama and language acquisition for English proficiency. California State University, Los Angeles, ProQuest, UMI Dissertations Publishing 1554673.

Bulut-Yılmaz, B. (2010). The effects of creative drama on children's vocabulary acquisition, a case study (Master's thesis). Gaziantep University, Turkey.

Brown, H. D. (1994). Principles of language learning and teaching. The USA: Pearson Education.

Campbell, P. A. (2008). Medea as Material: Heiner Müller, Myth, and Text. Modern Drama, 51(1), 84-103.

Clark, A. (2013). Whatever next? Predictive brains, situated agents, and the future of cognitive science. Behavioral and brain sciences, 36(3), 181-204.

Çelen, İ., \& Akar-Vural, R. (2009). Drama in education and teaching English: A research on the fourth-grade elementary students. Elementary Education Online, 8(2), 425438.

Demircioğlu, Ş. (2010). Teaching English vocabulary to young learners via drama. Procedia-Social and Behavioral Sciences, 2(2), 439-443.

Demirel, Ö. (1990). Yabancı dil ögretimi. Ilkeler, yöntemler, teknikler [Foreign language teaching. Principles, methods, techniques]. Ankara: USEM.

Desialova, L. (2009). Using different forms of drama in EFL classroom. Humanising language teaching, 11(4), ISSN: 1755-9715.

Dewey, J. 1921. The school and society. Chicago: University of Chicago Press.

Duffelmeyer, F. A., \& Duffelmeyer, B. B. (1979). Developing vocabulary through dramatization. Journal of Reading, 23(2), 141-143.

Fleming, Michael. (1995) Starting Drama Teaching. London: David Fulton Publishers.

Freeman, G. D., Sullivan, K., \& Fulton, C. R. (2003). Effects of creative drama on selfconcept, social skills, and problem behavior. The Journal of Educational Research, 96(3), 131-138.

Gardner, H. (1993). Creating minds: an anatomy as seen through the lives of Freud, Einstein, Picasso, Stravinsky, Eliot, Graham and Gandhi. The UK: HarperCollins Publishers.

Heathcote, D. (1984). Drama as a process for change. Dorothy Heathcote: Collected writings on education and drama, 18-25.

İpekboyayan, S. (1994) Primary Recommendations for Foreign Language Teaching. Language Journal, 21, 57-58.

Kelner, L.B. (1985). The Creative Classroom. Portsmouth: Heinemann.

Kim, K. H. (2006). Can we trust creativity tests? A review of the Torrance Tests of Creative Thinking (TTCT). Creativity research journal, 18(1), 3-14.

Köylüoğlu, N. (2010). Using drama in teaching English for young learners (Doctoral dissertation). Selçuk University, Turkey.

McCaslin, N. (1990) Creative Drama in the Classroom \& Beyond. Studio City, CA: Players Press.

McLoughlin, C. (1999). The implications of the research literature on learning styles for the design of instructional material. Australasian Journal of Educational Technology, 15(3).

Moore, M. M. (2004). Using drama as an effective method to teach elementary students. Senior Honors Theses, 113, 1-32. 
Ozdemir, S. M., \& Cakmak, A. (2008). The Effect of Drama Education on Prospective Teachers' Creativity. Online Submission, 1(1), 13-30.

Saraç, G. (2007). The use of creative drama in developing the speaking skills of young learners. Ankara: Gazi University Institute of Educational Sciences.

Schmitt, N. (2008). Instructed second language vocabulary learning. Language teaching research, 12(3), 329-363.

Slade, P. (1954). An introduction to child drama. University of London Press.

Stewing, W.J., Buege, C. (1994). Dramatizing Literature in Whole Language Classrooms. Second Edition. New York: Teachers College Press. Columbia University.

Su Bergil, A., Ercevik, A., Erdem, G. (2017) "Elaborating Teaching English to Young Learners Courses with Creative Drama: Alternatives for Prospective Teachers." International Journal of Research Granthaalayah, 5(12), 232-245.

Taşkın-Can, B. (2013). The Effects of Using Creative Drama in Science Education on Students \'Achievements and Scientific Process Skills. Illköğretim Online, 12(1), 120-131.

Torrance, E. P. (1977). Discovery and nurturance of giftedness in the culturally different. Reston, VA: Council on Exceptional Children.

Uysal, N. D., \& Yavuz, F. (2015). Teaching English to Very Young Learners. Procedia Social and Behavioral Sciences, 197, 19-22.

Wooster, R. (2007). Contemporary theatre in education. Bristol: Intellect Books.

Yllmaz, G., \& Dollar, Y. K. (2017). Attitudes of Turkish EFL Learners towards the Use of Drama Activities in English. HAYEF Journal of Education, 14(1), 245-277. 